\title{
Techno-Economic and Environmental Analysis of Wind-Diesel Power System
}

\author{
Ghanshyam Jayswal \\ M.Tech Scholar, Electrical Engineering Department \\ YIET, Gadhauli \\ Yamunanagar, Haryana
}

\author{
Gagan Deep Yadav \\ A.P., Electrical Engineering Department \\ YIET, Gadhauli \\ Yamunanagar, Haryana
}

\begin{abstract}
This paper discusses the economic analysis and environmental impacts of integrating a photovoltaic (PV) array into diesel-electric power systems for remote villages. MATLAB Simulink is used to match the load with the demand and apportion the electrical production between the PV and diesel-electric generator. The economic part of the model calculates the fuel consumed, the kilo watt hours obtained per gallon of fuel supplied, and the total cost of fuel. The environmental part of the model calculates the particulate matter (PM), $\mathrm{NO}_{\mathrm{x}}$ and $\mathrm{CO}_{2}$ emitted to the atmosphere. Simulations were performed for three cases: 1) diesel only; 2) diesel-battery; and 3) PV with diesel-battery using a one-year time period. The simulation results were utilized to calculate the energy payback, the simple payback time for the PV module, and the avoided costs of $\mathrm{CO}_{2}, \mathrm{NO}_{\mathrm{x}}$, and PM.
\end{abstract}

Keywords: Hybrid power system; Economical analysis; Technical analysis; Battery energy storage; Diesel engine.

\section{Introduction}

It is estimated that two billion people in small villages in developing countries currently lack grid-based electricity service. In many cases, grid extension is impractical because of dispersed populations, rugged terrain, or both. Thus, small off-grid stand-alone renewable energy systems represent an important option for narrowing the electricity gap in rural parts of the developing world, where progress in grid extension remains slower than population growth [1]. Even though these small-scale energy systems generate relatively little power, they can significantly contribute to life quality in remote locations in developing countries [2]. Cavello and Grub stress that $1 \mathrm{kWh}$ of electricity provides ten times more electricity services in India than in Indiana. They further state that two small wind generators, which would supply only two homes with electric heating in the United States, could pump water for 4000 people in Morocco [3].

In remote villages, far from the grids of many countries, electric energy is usually supplied by diesel generators or small hydroelectric plants. In most of these cases, the supply with diesel fuel becomes highly expensive while hybrid diesel/photovoltaic/wind generation becomes competitive with diesel-only generation [4].

$\mathrm{PV} /$ diesel/battery hybrid systems are more reliable in producing electricity than diesel only/PV-only systems, and often represent the best solution for electrifying remote areas. The diesel generator reduces the PV component while the PV systems decrease the operating time of the generator, reducing the running costs of the diesel generator [6] as well as the carbon emission. The addition of battery storage reduces the number of start/stop cycles of diesel generators, thus considerably minimizing fuel consumption [7] and [8].

The utilization of small-scale off-grid hybrid generation option is not yet in use in most part of the world, whose an important proportion of population is in rural areas that are neither grid-connected nor do they have independent generating plants. The main reason for this is the reliance on interconnected generation systems based on large-scale gas and oil plants. Electrical energy produced by these power stations is supplied to urban and some rural areas mainly through grid extension.

To solve the energy crisis electricity supplies could be provided through off-grid renewable energy options that are yet to be considered for parts of the world where a reasonable solar and/or wind resource is 
available. However, some research efforts to encourage the use of renewable energy have been conducted but without institutional support and interest. These include the estimation of the solar and wind energy potential of Algeria [9]; [10] and the situation of renewable energy in the country [11].

In this paper section I is dedicated to the introduction and background of small off-grid power system. In section II the modelling of different components of the system has been provided. Section III, the results are discussed for diesel only, wind-diesel and winddiesel-battery configuration. Conclusions and discussion has been made in section IV.

\section{Modelling of PV-diesel-battery Hybrid System}

The system proposed in this work is the technoeconomic comparison of the off-grid diesel only, PVdiesel and PV-diesel-battery system. So the modelling of PV system, diesel engine, and battery energy storage system has been discussed in detailed in this section.

\section{A. Modelling of PV System}

The equivalent electrical circuit of a PV cell is given in Fig. 1. It is a one diode model which is also known as the 5 parameter circuit. The cell can be modeled by other equivalent circuits as well; such as 7 parameters but the one diode model is the most commonly used circuit in the literature and the solution of the circuit is not as complicated as is the case in other models. The parameters in the circuit are; $\mathrm{I}_{\mathrm{D}}, \mathrm{I}_{\mathrm{L}}, \mathrm{I}_{\mathrm{SH}}, \mathrm{R}_{\mathrm{SH}}, \mathrm{R}_{\mathrm{S}}$, I and $\mathrm{V}$.

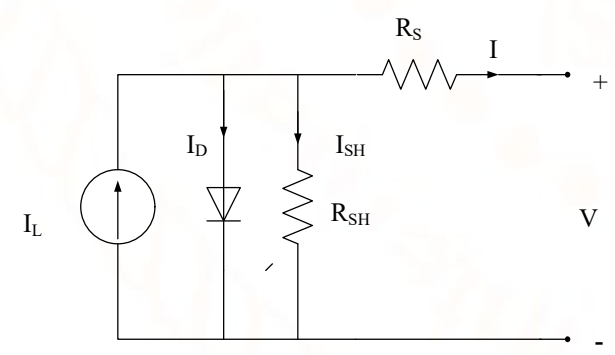

Fig. 1 Equivalent circuit of a solar cell.

From the circuit;

$I=I_{P H}-I_{D}-I_{S H}$

$\mathrm{I}_{\mathrm{PH}}$ (photo-generated current) is also called as $\mathrm{I}_{\mathrm{L}}$ (light current) which refers to direct current generated by photovoltaic effect. Whereas I is the output current of the cell.

From Shockley's diode equation;

$I_{D}=I_{0}\left[\exp \left(\frac{V+I R_{S}}{n V_{t}}\right)-1\right]$

Where;

$V_{t}=\frac{k T}{q}$

By Ohm's Law

$I_{S H}=\frac{V+I R_{S}}{R_{S H}}$

Equation (5) is the general solar cell characteristic equation which is available in the literature [4]. From the characteristic equation, it is possible to evaluate cell current for a given cell temperature and voltage. However, analytic solution of the equation is not possible and numerical methods will be used to solve the equation. The parameters that need to be defined before solving Equation (5) are after substituting equations (2), (3), and (4) into equation (1), the equation takes the form of;

$I_{D}=I_{P H}-I_{0}\left[\exp \left(\frac{V+I R_{S}}{A V_{t}}\right)-1\right]-\frac{V+I R_{S}}{R_{S H}}$

$\mathrm{R}_{\mathrm{SH}}, \mathrm{R}_{\mathrm{S}}, \mathrm{A}, \mathrm{I}_{\mathrm{PH}}$ and $\mathrm{I}_{0}$. These parameters are specific to every different commercial PV array and will be calculated from the product data sheet values tested at the Standard Test Conditions (STC) or Reference Point which is $1 \mathrm{~kW} / \mathrm{m} 2$ solar irradiation and $25^{\circ} \mathrm{C}$ cell temperature. Knowing these parameters, solar radiation data and the cell temperature will allow us to calculate the electricity generation of the solar cell.

\section{B. Modelling of Diesel Engine}

The diesel engine provides mechanical power to the synchronous machine. Its model is divided in three parts: engine, actuator and electronic control box.

The electronic control box and actuator represent the engine's speed governor. When operated in isochronous mode, the engine's governor regulates the fuel consumption according to the engine's speed; thus maintaining the DG speed and system's nominal 
frequency. Hence, when in isochronous mode, the engine's governor provides frequency regulation.

The diesel engine mathematical model is based on the work in [12]. This model has been widely use in previous power system studies [12]. The mathematical model is formed by separate high order transfer functions for the engine, actuator and electronic box, as depicted in Figure. 2.

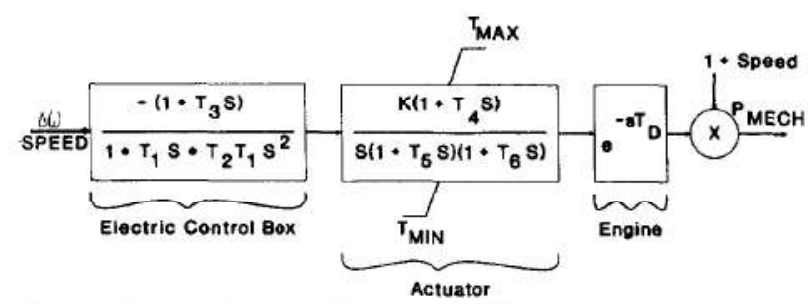

Fig.2 - Mathematical model of the diesel engine and governor [12]

The Engine block represents the engine dead time. Therefore, it has been implemented using a time delay. This mathematical model has been already implemented in SIMULINK and is available for use in the SimPower System's library. The engine parameters were extracted from study [13].

\section{Modelling of Battery Energy Storage System}

An electrical battery is chosen as energy storage system for this study. The complete BESS comprises: a battery, filter and IGBT converter

Various types of batteries can be used in power systems. Four of the most common battery types are: Lead Acid, Nickel Cadmium, Nickel Metal Hydride, Lithium-Ion. Although Nickel Metal Hydride (Ni$\mathrm{MH})$ batteries present a higher cost than other types, it has been chosen for its environmental-friendly aspect [13].

The battery mathematical model is based on reference [14]. The model in [14] has been widely used in power system studies. It has also been implemented in the SIMULINK' Sim Power Systems library. The model is implemented through a controllable voltage source regulated by Equation 1 and Equation 2.

$E=E_{0}-K\left(\frac{Q}{Q-\int i_{\text {batt }} d t}\right)+A^{-B \int i_{\text {batt }} d t}$

$V_{\text {batt }}=E_{\text {batt }}-i_{\text {batt }} R_{\text {batt }}$

(2)

where, $E$ is the internal voltage, $V_{\text {batt }}$ is terminal voltage and $i_{\text {batt }}$ is the current. The battery parameters, $\mathrm{A}, \mathrm{B}, \mathrm{K}, \mathrm{R}, \mathrm{Q}$ and $\mathrm{E}_{0}$, are defined in Table 1 .
Table-I Parameters of BESS

\begin{tabular}{|l|l|}
\hline Parameter & \multicolumn{1}{|c|}{ Definition } \\
\hline $\mathbf{A}$ & Exponential zone amplitude $(\mathrm{V})$ \\
\hline $\mathbf{B}$ & $\begin{array}{l}\text { Exponential zone time constant inverse } \\
\left(\mathrm{Ah}^{-1}\right)\end{array}$ \\
\hline $\mathbf{K}$ & Polarization voltage $(\mathrm{V})$ \\
\hline $\mathbf{R}_{\text {batt }}$ & $\mathrm{R}_{\text {batt }} \quad$ Battery internal resistance $(\Omega)$ \\
\hline $\mathbf{E}_{\mathbf{0}}$ & $\mathrm{E}_{0} \quad$ Battery constant voltage $(\mathrm{V})$ \\
\hline $\mathbf{Q}$ & $\mathrm{Q} \quad$ Capacity (Ah) \\
\hline
\end{tabular}

\section{Simulations and Results}

In this paper the simulations are done for the three cases:

1. Diesel only mode.

2. Diesel-Battery mode.

3. PV-Diesel-Battery mode.

For each case total cost of energy, carbon emission $\mathrm{PM}$ and $\mathrm{NO}_{\mathrm{x}}$, which are harmful to the environment are calculated one by one. Then comparison is made in the above said three cases.

Case I. Diesel only: For case I the diesel engine generator system is connected to the load.
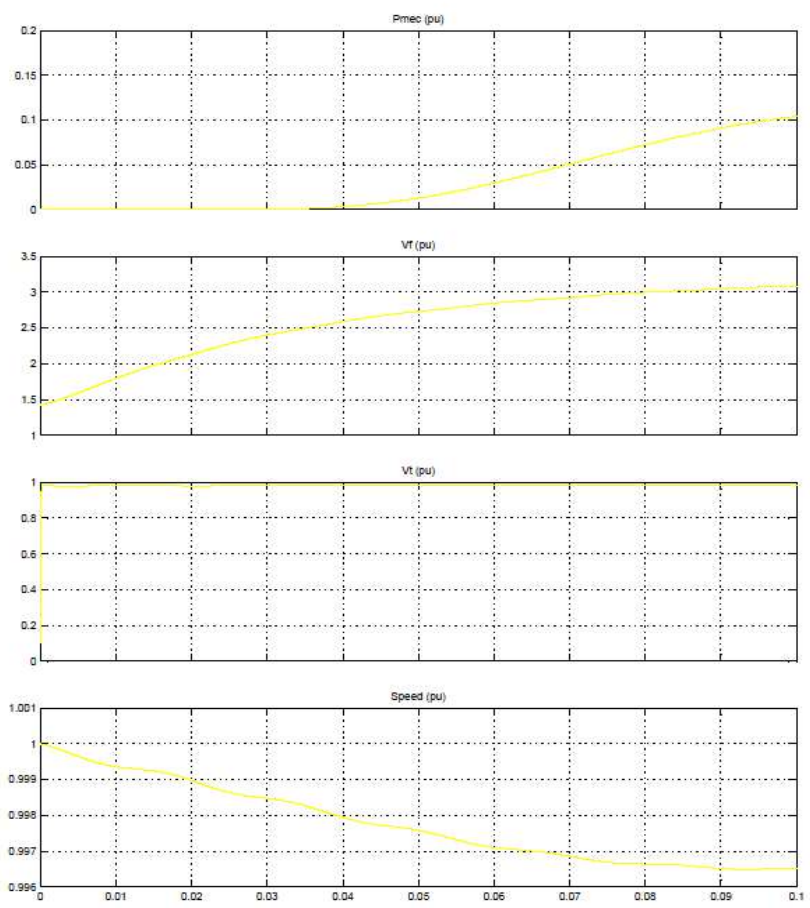

Time onseet 0 
Fig.3. Mechanical power(Pmec), Excitation voltage(Vf), Termianl voltage $(\mathrm{Vt})$ and generator $\operatorname{speed}(\mathrm{N})$ for case I
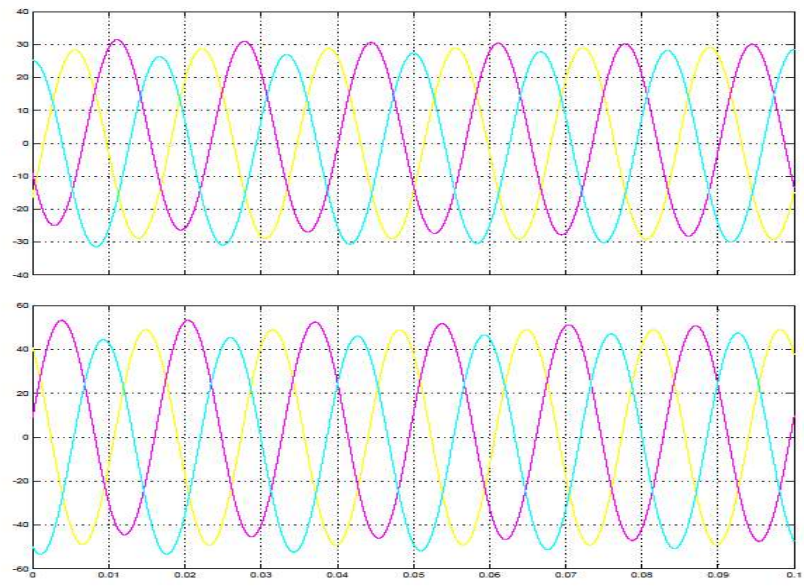

Fig.4. Terminal voltage and terminal current for case I The various electrical parameters are shown in fig. 3 and fig.4. All the demand is met by the diesel engine generator only. So carbon footprints and other harmful components to the environment will be more. Although the system efficiency will be more because of lesser components but this configuration is not desirable. Table II provides the various details for this configuration.

Table II. Various parameters in diesel only mode.

\begin{tabular}{|l|l|l|}
\hline S.No. & \multicolumn{1}{|c|}{ Parameters } & \multicolumn{1}{c|}{ Values } \\
\hline 1. & Mech. Input & $1.195^{*} 10^{5}$ Watt \\
\hline 2. & Fuel consumed & 8413 gallons \\
\hline $\mathbf{3 .}$ & Fuel cost & 33650 \$/gallon \\
\hline $\mathbf{4 .}$ & $\begin{array}{l}\text { Energy production per } \\
\text { gallon }\end{array}$ & $\begin{array}{l}10.61 \\
\mathrm{kwhr} / \text { gallon }\end{array}$ \\
\hline $\mathbf{5 .}$ & Carbon emission per unit & $8.81 * 10^{4}$ \\
\hline $\mathbf{6 .}$ & PM emission & 73.9 \\
\hline $\mathbf{7 .}$ & $\mathrm{NO}_{\mathrm{x}}$ emission & 1821 \\
\hline
\end{tabular}

Case II PV-Diesel Mode: In this configuration diesel engine driven synchronous generator as well as PV system is simultaneously run together. Part of the load is fed by the PV system and remaining is fed by the diesel engine. As the load is shared by the PV system also, so that the fuel consumption will be less and carbon emission will be less as compare to case I. The system frequency will be lesser because of less efficiency of PV system.
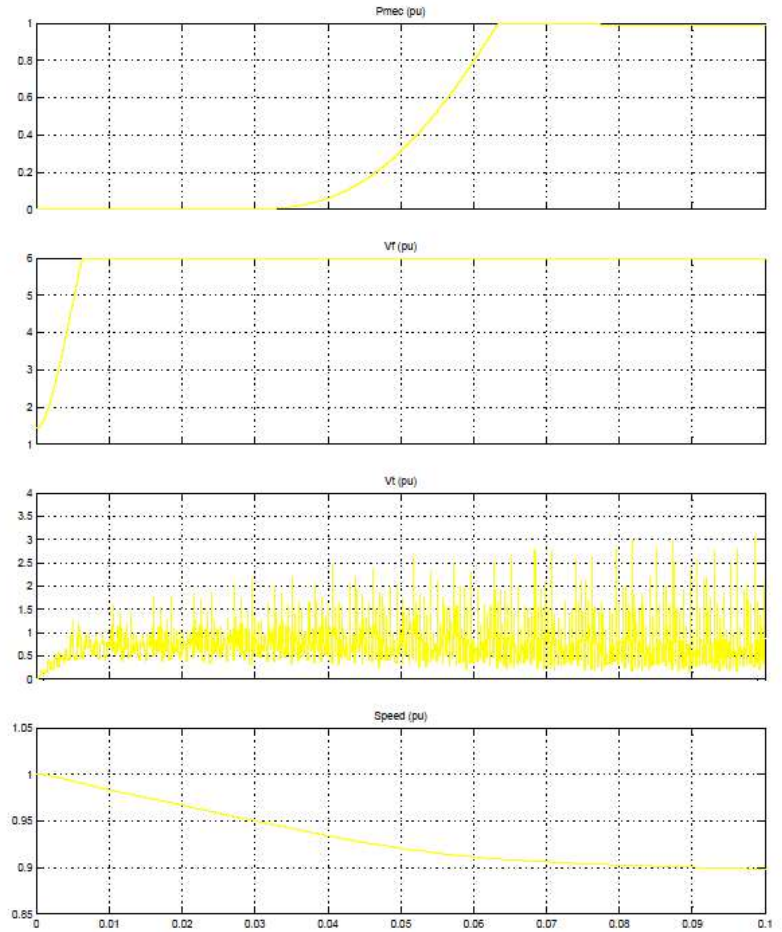

Fig.5. Mechanical power(Pmec), Excitation voltage(Vf), Termianl voltage $(\mathrm{Vt})$ and generator speed(N) for case II
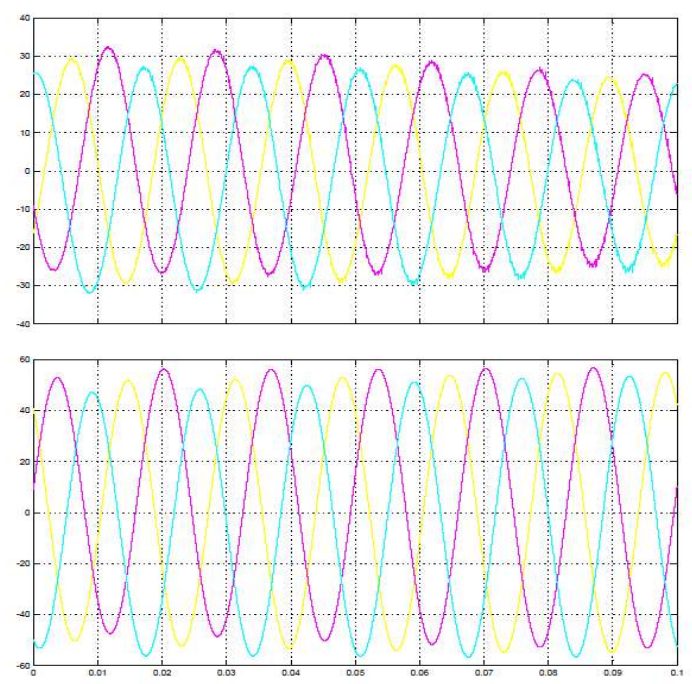

Fig.6. Terminal voltage and terminal current for case II 
Table III. Various parameters in diesel-battery mode.

\begin{tabular}{|l|l|l|}
\hline S.No. & Parameters & Values \\
\hline 1. & Mech. Input & $1.03^{*} 10^{5}$ Watt \\
\hline 2. & Fuel consumed & 7367 gallons \\
\hline 3. & Fuel cost production per & $\begin{array}{l}12.19 \\
\mathrm{kwhr} / \text { gallon }\end{array}$ \\
\hline 4. & $\begin{array}{l}\text { Energy gallon } \\
\text { gallon }\end{array}$ & $7.164^{*} 10^{4}$ \\
\hline 5. & Carbon emission per unit & 72.2 \\
\hline 6. & PM emission & 1730 \\
\hline 7. & $\mathrm{NO}_{\mathrm{x}}$ emission & \\
\hline
\end{tabular}

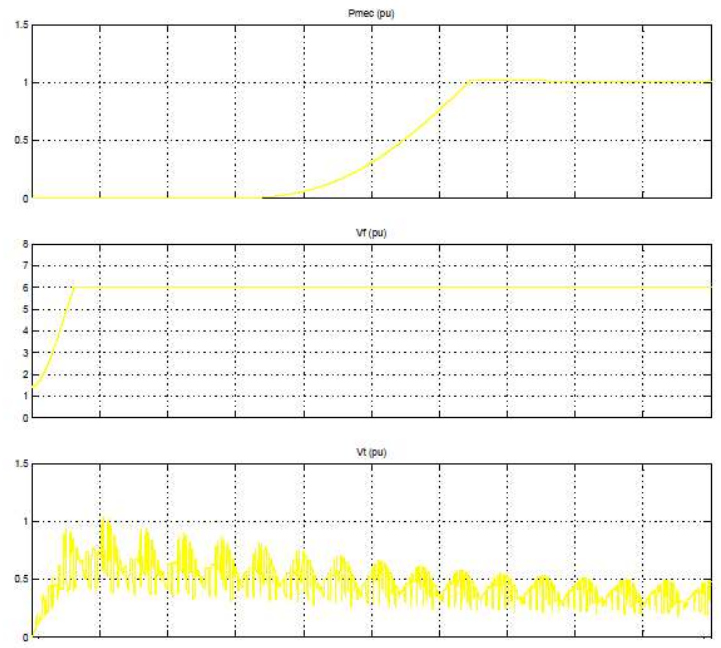

In Table III the various parameters are shown. From here it can be seen that the fuel consumption and fuel cost is lesser as compared to case I. The carbon emission, NOx and PM emission is lesser. The electricity produced per gallon is more as compare to case I. In the comparison with technical aspects the waveforms of voltage and currents are somewhat distorted as compared to the case I.

Table IV. Various parameters in diesel-PV-battery mode.

\begin{tabular}{|l|l|l|}
\hline S.No. & \multicolumn{1}{|c|}{ Parameters } & \multicolumn{1}{c|}{ Values } \\
\hline 1. & Mech. Input & $0.93 * 10^{5}$ Watt \\
\hline 2. & Fuel consumed & 6588 gallons \\
\hline $\mathbf{3 .}$ & Fuel cost & 26350 \$/gallon \\
\hline $\mathbf{4 .}$ & $\begin{array}{l}\text { Energy production per } \\
\text { gallon }\end{array}$ & $\begin{array}{l}14.11 \\
\mathrm{kwhr} / \text { gallon }\end{array}$ \\
\hline $\mathbf{5 .}$ & Carbon emission per unit & $6.407 * 10^{4}$ \\
\hline $\mathbf{6 .}$ & PM emission & 57.32 \\
\hline $\mathbf{7 .}$ & $\mathrm{NO}_{\mathrm{x}}$ emission & 1426 \\
\hline
\end{tabular}

Case III PV-Diesel-Battery: In this configuration the battery is also connected with diesel and PV system. The battery will reduce the number of start and stop of diesel engine. The battery energy storage system also shifts the peak power production to the valley power demand.

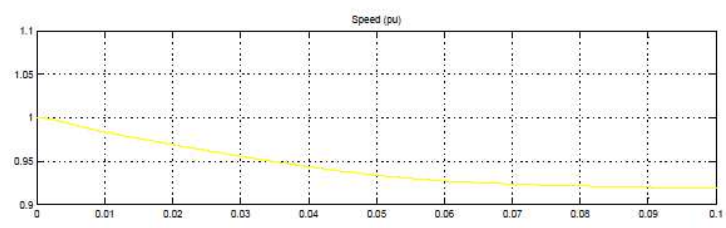

Fig. 7. Mechanical power(Pmec), Excitation voltage $(\mathrm{Vf})$, Termianl voltage $(\mathrm{Vt})$ and generator speed(N) for case III
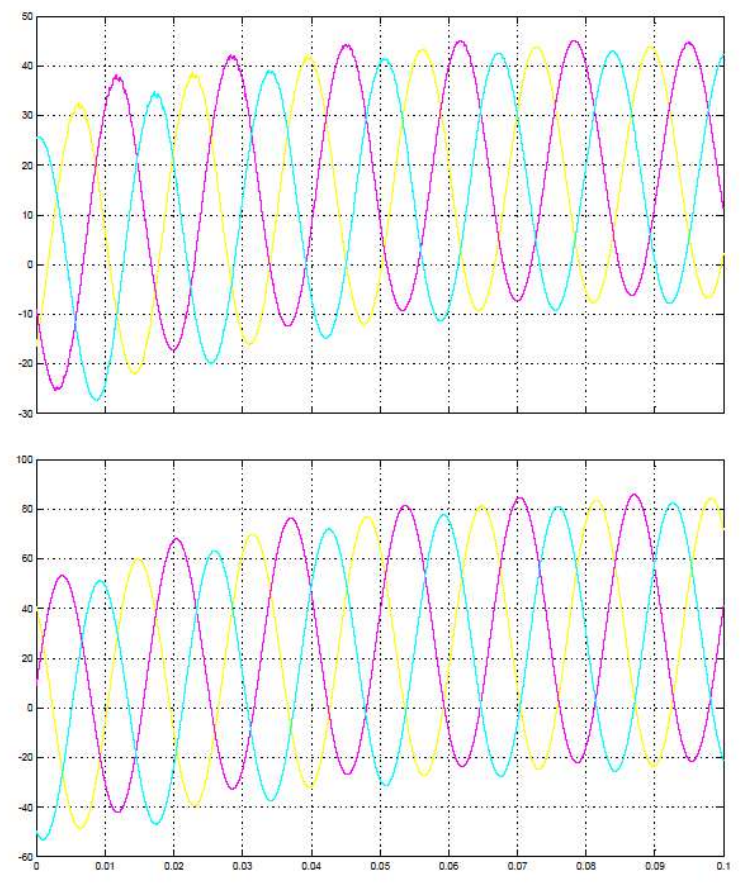

Fig.8. Terminal voltage and terminal current for case III 


\section{Conclusions}

In this paper the comparison of the diesel only, dieselbattery and PV-diesel-battery system is compared. From the simulation it is found that the carbon emission is most in diesel only mode as expected and least in diesel-PV-battery mode. The power quality is best in diesel only mode and it reduces in dieselbattery mode and power quality more reduces in diesel-PV-battery mode.

The carbon footprints, PM and NOx is also reduces in as going from diesel only to diesel-battery to dieselPV-Battery mode. So, from this study it is found that more the penetration of $\mathrm{PV}$ in system will reduce the cost as well as the harmful components to the environment but power quality also reduces.

\section{References}

[1] Barley CD. "Optimal dispatch strategy in remote hybrid power systems”. Sol Energy 1996;58:16579.

[2] Bryne J, Shen B, Wallace B. "The economics of sustainable energy for rural development: a study of renewable energy in China". Energy Policy 1998;26:45-54.

[3] Celik AN. "A simplified model for estimating yearly wind fraction". Renew Energy 2006;31:105-18.

[4] Cavello AJ, Grubb AM. "Renewable energy sources for fuels and electricity". London: Earthscan; 1993.

[5] Colle S, Abreu SL, Ruther R. "Economic evaluation and optimisation of hybrid diesel/photovoltaic systems integrated to electricity grid". Sol Energy 2004;76:295-9.

[6] Muselli M, Norton G, Louche A. "Design of hybrid photovoltaic power generator, with optimisation of energy management". Sol Energy 1999;65(3):143-57.

[7] Elhadidy MA, Shaahid SM. "Optimal sizing of battery storage for hybrid (wind \& diesel) power systems". Renew Energy 1999;18:77-86.

[8] Elhadidy MA. "Performance evaluation of hybrid (wind/solar/diesel) power systems". Renew Energy 2002;18:401-13.

[9] Office National de la Météorologie. Atlas climatologique national. Recueil de données, période (1975-1984).
[10] Hammouche R. Atlas vent de l'Algérie. Office national de la météorologie. Alger: Edition OPU; 1990.

[11] B. Sedaghat, A. Jalilvand and R. Noroozian, "Design of a multilevel control strategy for integration of stand-alone wind/diesel system," International Journal of Electrical Power \& Energy Systems, vol. 35, 2012, pp. 123-137.

[12] R. Sebastian, "Modelling and simulation of a high penetration wind diesel system with battery energy storage," International Journal of Electrical Power \& Energy Systems, vol. 33, no.3, 2011, pp. 767-774.

[13] R. Sebastián and R. P. Alzola, "Effective active power control of a high penetration wind diesel system with a Ni-Cd battery energy storage," Renewable Energy, vol. 35, 2010, pp. 952-965.

[14] R. Sebastián, "Reverse power management in a wind diesel system with a battery energy storage," International Journal of Electrical Power \& Energy Systems, vol. 44, no. 1, 2012, pp. 160-167. 